\title{
JAK STAWIĆ CZOŁA NOWOCZESNOŚCI? DYSKUSJA WOKÓŁ WZORCA NIEMIECKIEJ SZLACHCIANKI NA ŁAMACH „DEUTSCHES ADELSBLATT” NA PRZEŁOMIE XIX I XX WIEKU*
}

Zarys treści: Artykuł prezentuje poglądy publikowane na łamach niemieckiego tygodnika „Deutsches Adelsblatt” na przełomie XIX i XX w. na temat wpływu przemian społeczno-gospodarczych i postępu cywilizacyjnego na życie szlachcianek. Towarzyszy temu uzupełnienie katalogu zadań i powinności kobiecych o nowe elementy, takie jak lepsza edukacja i możliwość pracy zarobkowej. Budowany w ten sposób wzorzec niemieckiej, nowoczesnej szlachcianki wzmocniony został kontekstem stanowo-nacjonalistycznym, który - w opinii publicystów - czynił kobiety odpowiedzialnymi za przyszłość szlachty i państwa.

The content outline: The paper presents the opinions expressed on the pages of the German weekly Deutsches Adelsblatt at the turn of the $20^{\text {th }}$ century in relation to the issue of the influence of social-economic changes and the advancement of civilisation on the life of noblewomen. These reflections served to update the catalogue of a woman's tasks and obligations with new elements, such as better education and possibility of employment. The model of a modern noblewoman constructed by these means was reinforced with class-nationalist context, which, according to the opinion of journalists - made women responsible for the future of the German nobility and state.

Słowa kluczowe: szlachta niemiecka w XIX wieku, historia kobiet, modernizacja, publicystyka szlachecka

Keywords: German nobility in the $19^{\text {th }}$ century, women's history, modernisation, noble journalism

* Materiały wykorzystane do napisania artykułu zebrano w ramach realizacji grantu habilitacyjnego MNiSW NN 108320137. 
Przemiany gospodarcze i polityczne dokonujące się w wieku XIX postawiły nie tylko niemiecką szlachtę przed koniecznością przedefiniowania swoich zadań w państwie i społeczeństwie. Likwidacja feudalizmu i industrializacja niszczyły świat, w którym odgrywała wiodąca oraz przywódczą rolę, czyniąc z niej jako stanu relikt przemijającego, agrarnego społeczeństwa. Problematyka tzw. dopasowywania się prusko-niemieckiej szlachty do nowej rzeczywistości stanowi od lat wciąż obszar intensywnych badań historyków zza Odry i obfituje w szereg ustaleń dotyczacych działań podejmowanych przez przedstawicieli tego stanu w ramach strategii „pozostania na szczycie”. Ustalenia te dotyczą nie tylko kwestii związanych z wypieraniem szlachty z dotychczasowych, zarezerwowanych wyłącznie dla niej sfer działalności w administracji i w gospodarce, ale także łączących się z dążeniem do utrzymania wewnątrzstanowej homogeniczności. Procesy modernizacji² nabierające tempa w drugiej połowie XIX i na początku XX stulecia stanowiły bowiem zagrożenie dla szlacheckich wartości i stylu życia. Wpływały na zmianę uświęconych tradycją wzorów zachowań, w tym również określających zadania i pozycję kobiet z tego stanu. W tych okolicznościach na łamach ukazującego się w Berlinie od 1883 r. tygodnika „Deutsches Adelsblatt” zapoczątkowana została dyskusja na temat działań, jakie powinna podjać szlachta wobec wyzwań stawianych przez nową zmieniająca się rzeczywistość. Periodyk ten był organem Stowarzyszenia Szlachty Niemieckiej ${ }^{3}$ (Deutsche Adelsgenossenschaft), które powstało

${ }^{1}$ R. Braun, Konzeptionelle Bemerkungen zum „Obenbleiben”. Adel im 19. Jahrhundert, w: Europäische Adel 1750-1950, red. H.-U. Wehler, Göttingen 1990, s. 87-95; Aufsteigen und Obenbleiben in europäischen Gesellschaften des 19. Jahrhunderts. Akteure-Arenen-Aushandlungsprozesse, red. K. Holsten, D. Hüchtker, M.G. Müller, Berlin 2009; Der Schritt in die Moderne. Sächsischer Adel zwischen 1763 und 1918, red. S. Marburg, J. Matzerath, Köln 2001; Ostelbische Agrargesellschaft im Kaiserreich und in der Weimarer Republik. Agrarkrise-junkerliche InteressenpolitikModernisierungsstrategien, red. H. Reif, Berlin 1994; R. Schiller, Vom Rittergut zum Grossgrundbesitz. Ökonomische und soziale Transformationsprozesse der ländlichen Eliten in Brandenburg im 19. Jahrhundert, Berlin 2003; M. Wienfort, Der Adel in der Moderne, Göttingen 2006.

${ }^{2}$ Modernizacja jako pojęcie mające oddać istotę przemian dokonujacych się w Europie od przełomu XVIII i XIX w. ma już swoją obszerną literaturę, a teorie wypracowane na jej gruncie uwzględniają szereg perspektyw, nie tylko historyczna. Od lat 90. XX w. widoczne jest ponowne zainteresowanie tą problematyką związane z reinterpretacja dokonanych wcześniej ustaleń. Zob. m.in.: A. Langenohl, Tradition und Gesellschaftskritik: Eine Rekonstruktion der Modernisierungstheorie, Frankfurt a. M. 2007; U. Beck, A. Giddens, S. Lash, Modernizacja refleksyjna, Warszawa 2009.

${ }^{3}$ Stowarzyszenie było jedna z organizacji szlacheckich powstałych w Niemczech w końcu XIX w. W 1869 r. zawiązało się zdominowane przez szlachtę westfalską 
również w Berlinie, w 1874 r. z inicjatywy kilkunastu właścicieli ziemskich należących do konserwatywnej, drobnej i legitymującej się dawnym rodowodem szlachty z pięciu wschodnich prowincjach Prus (Brandenburgia, Pomorze, Prusy Wschodnie, Saksonia i Śląsk). Początkowo zrzeszać miało tylko ziemian, jednak już w latach 80. XIX w. warunek ten zastapiono wymogiem posiadania odpowiedniej do szlacheckiego pochodzenia pozycji społecznej. Stowarzyszenie Szlachty Niemieckiej stawiało sobie za cel wspieranie coraz liczniejszej grupy zubożałych szlachciców czy też, jak wówczas mówiono, „proletariatu szlacheckiego”, a więc tych, którzy pozbawieni przywilejów przegrali w konfrontacji ze światem stawiajacym na obce temu stanowi dażenie do zysku i zdobywania wiedzy. Organizacja ta nie miała jednak charakteru opiekuńczego, mimo że inspirowała także i akcje tego rodzaju. Owo zapisane w statucie wspieranie szlachty oznaczało bowiem aktywność na rzecz zapewnienia należnego jej - jak sądzono - wiodącego miejsca w życiu publicznym. Już u schyłku XIX w. zubożali przedstawiciele tego stanu, pozbawieni ziemi i znaczenia, zmuszeni do imania się zarobkowo różnych zajęć dominowali w stowarzyszeniu, które tuż przed wybuchem I wojny liczyło około 2500 członków $^{4}$.

Na łamach „Deutsches Adelsblatt” (wydawanego nieprzerwanie niemal do końca II wojny światowej, ale wznowionego już w latach 40. XX w. i ukazującego się do dziś) wiele uwagi poświęcano poszukiwaniu odpowiedzi na pytanie jak pogodzić trudności ekonomiczne szlachty z utrzymaniem przez nią odpowiedniej pozycji społecznej i stylu życia. W publicystce tej nie zabrakło również odniesień do sytuacji szlachcianek. Bezpośrednim impulsem skłaniającym do podjęcia tego tematu był los córek oficerów, niższych urzędników czy zadłużonych ziemian. Zazwyczaj pozbawione posagu, miały słabą pozycję

Stowarzyszenie Katolickiej Szlachty Niemiec (Verein katholischer Edelleute Deutschlands), w 1876 r. Stowarzyszenie Katolickiej Szlachty w Bawarii (Genossenschaft katholischer Edelleute in Bayern), a w 1890 r. Zrzeszenie Katolickiej Szlachty na Ślasku (Vereinigung der katholischer Edelleute in Schlesien). Wymienione organizacje w odróżnieniu od Stowarzyszenia Szlachty Niemieckiej miały charakter regionalny i konfesyjny. S. Malinowski, Vom König zum Führer. Sozialer Niedergang und politische Radikalisierung in deutscher Adel zwischen Kaiserreich und NS-Staat, Berlin 2003, s. 144-145; H. Conrad, Stand und Konfession. Der Verein der katholischen Edelleute. Teil 1: Die Jahre 1857-1918, „Westfälische Zeitschrift - Zeitschrift für vaterländische Geschichte und Altertumskunde" 158, 2008, s. 176.

4 Tenże, „Führertum” und,„Neuer Adel”. Die Deutsche Adelsgenossenschaft und der Deutsche Herrenklub in der Weimarer Republik, w: Adel und Bürgertum in Deutschland, red. H. Reif, t. 2: Entwicklungslinien und Wendepunkte im 20. Jahrhundert, Berlin 2001, s. 179-182. 
na rynku małżeńskim i w związku z tym - relatywnie częściej niż szlachcianki z lepiej sytuowanych domów - późno wychodziły za mąż lub nigdy nie stawały na ślubnym kobiercu. Po śmierci rodziców nie zawsze mogły też liczyć na opiekę ze strony rodziny i tym samym skazane były na samotne życie bez zabezpieczenia finansowego ${ }^{5}$. W tej sytuacji publicyści „Deutsches Adelsblatt”, chroniąc tradycyjny system wartości, starali się wskazać szlachciankom właściwy dla nich modus vivendi. Kwestia ta wpisuje się zresztą w szerszą dyskusję toczącą się w tym periodyku na temat zagrożeń, jakie z perspektywy niemieckiej szlachty niosła nowoczesność i co za tym idzie - form obrony mającej na celu utrzymanie przez nia wiodącej roli w nowym, industrialnym świecie. Celem niniejszego artykułu jest więc z jednej strony przedstawienie poglądów prezentowanych we wspomnianym tygodniku na temat wpływu przemian społeczno-obyczajowych i postępu cywilizacyjnego na życie szlachcianek, z drugiej zaś - wskazanie, jaką miały odegrać rolę w programie reformy wewnętrznej stanu. Z kwestią tą wiąże się również pytanie, na ile $\mathrm{w}$ formułowanym przy tej okazji katalogu zadań i powinności kobiecych uwzględniony został wpływ zmian, jakie niosła nowoczesność i czy w związku z tym na przełomie XIX i XX w. można mówić o narodzinach nowego wzorca osobowego szlachcianki ${ }^{6}$ ?

Publicystyka „Deutsches Adelsblatt”, będąca przecież głosem Stowarzyszenia Szlachty Niemieckiej, stanowiła wyraz poglądów agrariuszy zamieszkałych na wschodzie cesarstwa ${ }^{7}$, dlatego też zrozumienie postaw

5 J.M. Singer, Arme adlige Frauen im Deutschen Kaiserreich, Tübingen 2016, s. $109-116$.

${ }^{6}$ Szlacheckie ideały wychowawcze i wzorce zachowań dotyczące męskiej części stanu szlacheckiego znalazły swoje omówienie w publikacji: M. Funck, S. Malinowski, „Charakter ist alles!" Erziehungsideale und Erziehungspraktiken in deutschen Adels. familien des 19. und 20. Jahrhunderts, „Jahrbuch für Historische Bildungsforschung” 6, 2000, s. 71-91. Perspektywa kobieca została natomiast częściowo ujęta w najnowszych pracach na temat niemieckich szlachcianek: O. Wörner-Heil, Adelige Frauen als Pionierinnen der Berufsbildung. Die ländliche Hauswirtschaft und der Reifensteiner Verband, Kassel 2010; M. Kubrova, Vom guten Leben. Adelige Frauen im 19. Jahrhundert, Berlin 2011; D. Menning, Standesgemäße Ordnung in der Moderne. Adlige Familienstrategien und Gesellschaftsentwürfe in Deutschland 1840-1945, München 2014; oraz J.M. Singer, dz. cyt. W publikacjach tych zajmowano się jednak przede wszystkim praktyką wychowawcza, nie zaś odnoszącymi się do tych kwestii postulatami zawartymi w publicystyce szlacheckiej.

${ }^{7}$ Szlachta niemiecka jako stan nie była homogeniczna. Dzieliły ją nie tylko kwestie religijne, miejsce w hierarchii wewnątrzszlacheckiej, sytuacja ekonomiczna, ale przede wszystkim odrębności regionalne. Po zjednoczeniu Niemiec partykularyzmy te nie zanikły. Wciąż na pierwszym miejscu była wierność krajowi, a nie wierność Cesarstwu. N. Elias, Rozważania o Niemcach, Poznań 1996, s. 90-91. 
i poglądów szlachty prusko-niemieckiej wymaga szerszego spojrzenia na jej sytuacje z trzech perspektyw, tj. przemian gospodarczych, nasilających się od końca XIX w. procesów modernizacji oraz utrwalonych tradycja atrybutów składajacych się na wzorzec osobowy szlachcianki.

Na terenie Niemiec w XIX w. najszybciej na drogę reform weszły Prusy i to one zadecydowały o obliczu procesów modernizacji wiążących się z przechodzeniem od społeczeństwa agrarnego do industrialnego. Oparcie gospodarki rolnej na zasadach kapitalistycznych, postępujące uprzemysłowienie, urbanizacja oznaczały dla szlachty nie tylko ze wschodnich, agrarnych prowincji państwa konieczność odnalezienia się w nowej sytuacji, zwłaszcza że w wyniku realizowanych równocześnie reform polityczno-ustrojowych traciła ona także uprzywilejowana pozycję w państwie. Świat, w którym odgrywała wiodącą rolę stopniowo odchodził do przeszłości, jednak mimo to starała się ona zachować jak najwięcej elementów stanowiących podstawę jej dotychczasowego statusu. Politycznym instrumentem ochrony interesów agrariuszy z obszarów na wschód od Łaby stała się ukonstytuowana na nowo w 1876 r. w zjednoczonych Niemczech partia konserwatywna (Deutschkonservative Partei), która była niechętna jakimkolwiek reformom ustroju społeczno-politycznego ${ }^{8}$. Zasadniczą kwestią determinująca stosunek szlacheckich posiadaczy ziemskich do zmian niesionych przez nowoczesność był kryzys rolny związany z napływem do Europy po 1860 r. taniego zboża amerykańskiego i rosyjskiego, pogłębiony jeszcze krachem grynderskim oraz kilkunastoletnią dekoniunktura zapoczątkowaną w 1873 r. Przeobrażenia na światowym rynku produktów rolnych wynikały bowiem z jednej strony z zastosowania wielu ulepszeń w technice upraw, przekładających się na wzrost możliwości produkcyjnych, z drugiej zaś - z rewolucyjnych zmian w transporcie (koleje żelazne, usprawnienia w żegludze) powodujących obniżenie kosztów przewozu. Mimo iż państwo wyszło naprzeciw interesom wielkiej własności i w 1880 r. dokonało protekcjonistycznego zwrotu w polityce, to jednak w świadomości posiadaczy ziemskich zakorzeniła się już myśl nieodwracalnego załamania rynku zbożowego, powodując pesymistyczne wizje wynikajacych stąd zagrożeń. Dramatyczne oceny sytuacji publikowane były na łamach periodyków towarzystw rolniczych ${ }^{9}$. Nie brakowało ich

${ }^{8}$ H. Beck, Konservative Politik und Modernisierung in Preußen, w: Pommern im 19. Jahrhundert. Staatliche und gesellschaftliche Entwicklung in vergleichender Perspektive, red. T. Stamm-Kuhlmann, Köln-Weimar-Wien 2007, s. 26-27.

9 W. Stępiński, Wielka własność ziemska na Pomorzu Zachodnim i państwo pruskie w latach 1806-1914, w: Szlachta - spoteczeństwo - państwo między Warmiq a Rugia w XVIII-XX wieku, red. M. Jaroszewicz i W. Stępiński, Szczecin 1998, s. 56-62; tenże, 
tė̇ w konserwatywnej prasie, nie tylko w sztandarowym „Neue PreuBische Zeitung", ale także i innych związanych z tym nurtem, m.in. „Deutsches Adelsblatt”"10. Słabnąca pozycja ekonomiczna szlacheckich posiadaczy ziemskich w przemysłowym państwie rekompensowana była jednak wpływami politycznymi i przywództwem na obszarach wiejskich, gdzie utrzymywano ducha starych, feudalnych czasów.

Zmiany te miały również swoje przełożenie na mikropłaszczyznę indywidualnych postaw i odczuć, tak istotnych dla pełnego zrozumienia publicystyki szlacheckiej tego okresu. Pełniejszy obraz sytuacji szlachty umożliwia spojrzenie na nia przez pryzmat założeń teorii modernizacji1 ${ }^{11}$ W nauce zwraca się bowiem uwagę na szczególny charakter wkraczania Niemiec w nowoczesnośćc ${ }^{12}$, zwłaszcza Prus wyróżniających się silna pozycja wspieranych przez państwo szlacheckich posiadaczy ziemskich. Znalazł on swoje odzwierciedlenie w literaturze przedmiotu w postaci terminu „modernizacji cząstkowej” czy też - jak uważa Hans-Ulrich Wehler - bardziej adekwatnej pojęciowej konstrukcji, tj. „modernizacji defensywnej”" ${ }^{\text {. }}$. Program reform zrealizowany w Prusach na początku wieku XIX zmienił stosunki wiejskie i rozpoczą proces

Państwo, „dyktat pośrednictwa” a powstanie Izby Rolniczej Pomorza Zachodniego w latach 1893-1897. W kwestii genezy nowoczesnych ugrupowań agrarnego interesu Rzeszy wilhelmińskiej, w: Państwo i społeczeństwo na Pomorzu Zachodnim do 1945 roku, red. W. Stępiński, Szczecin 1997, s. 259-262; H. Hainisch, Agrarstaat oder Industriestaat. Die Debatte um die Bedeutung der Landwirtschaft in Wirtschaft und Gesellschaft Deutschlands an der Wende vom 19. zum 20. Jahrhundert, w: Ostelbische Agrargesellschaft im Kaiserreich und in der Weimarer Republik, red. H. Reif, Berlin 1994, s. 33-50; H.J. Puhle, Agrarische Interessenpolitik und preußischen Konservatismus im wilhelminischen Reich (1893-1914), Bonn 1980.

${ }^{10}$ D. Bussiek, „Mit Gott für König und Vaterland!“ Die Neue Preußische Zeitung (Kreuzzeitung) 1848-1892, Münster 2002.

${ }_{11}$ Na temat teorii modernizacji w odniesieniu do dziejów Niemiec zob.: L. Dittmer, Beamtenkonservatismus und Modernisierung, Wiesbaden 1992; F.-M. Kuhlemann, Modernisierung und Disziplinierung: Sozialgeschichte des preußischen Volksschulwesens 1794-1872, Göttingen 1992; T. Nipperdey, Problemy modernizacji w Niemczech, w: tenże, Rozważania o niemieckiej historii, Warszawa 1999, s. 67-91; D. Rüschmeyer, Partielle Modernisierung, w: Theorien des sozialen Wandels, red. W. Zapf, Köln 1969, s. 382-396; H.-W. Wehler, Teoria modernizacji a historia, w: tenże, Modernizacja, nacjonalizm, państwo. Eseje i artykuty, Warszawa 2001, s. 47-141. Spośród prac historycznych dotyczących bezpośrednio omawianego obszaru por.: D. Millies, Modernisierung in der preußischen Provinz? Der Regierungsbezirk Stettin im 19. Jahrhundert, Göttingen 2012 (zob. zwłaszcza interesujące rozważania dotyczące znaczenia pojęcia modernizacja w odniesieniu do dziejów Prus/Niemiec w XIX wieku, s. 25-28).

${ }_{12} \mathrm{Na}$ temat niejednoznacznego rozumienia tego pojęcia: J. Osterhammel, Historia XIX wieku. Przeobrażenie świata, Poznań 2013, s. 1191-1193.

${ }^{13}$ H.-W. Wehler, Teoria..., s. 118. 
tworzenia nowego społeczeństwa opartego na zasadzie równości wobec prawa, wspieranej nowymi rozwiązaniami ustawowymi przełamującymi bariery krępujące mobilność, zarówno pionowa, jak i pozioma. Przebudowa nie objęła jednak oblicza politycznego kraju, co w konsekwencji doprowadziło do umocnienia preindustrialnej elity szlacheckich posiadaczy ziemskich w nowych warunkach gospodarki kapitalistycznej ${ }^{14}$. Państwo, opierające się wciąż na konserwatywnych podstawach, wpierało swoim autorytetem dokonujące się zmiany, stwarzając tym samym możliwość współistnienia tradycyjnych i nowoczesnych struktur. Po zjednoczeniu Niemiec pruska szlachta, będąca zasadniczo ostoja starego, przednowoczesnego porządku, weszła w epokę przyspieszonej industrializacji pewna swojej pozycji i znaczenia oraz trwałości i niewzruszalności wyznawanych poglądów. Była jednak nieprzygotowana na nowoczesność. Spowodowało to z jednej strony poczucie niepewności statusu i zachwiania norm, z drugiej zaś - wyobcowanie przekładające się na dyskomfort wynikający z trudności w zaakceptowaniu skutków postępu technicznego i szybkiego tempa industrializacji. W tej sytuacji głos rzeczników tradycyjnego świata prezentowany na łamach „Deutsches Adelsblatt” stanowi próbę „uporania się” z nowoczesnościa poprzez zdefiniowanie pozycji szlachty w nowym otoczeniu i nadanie sensu istnienia $\mathrm{w}$ industrialnym świecie, a poprzez to wzmocnienie podstaw budujących jej stanową tożsamośćc ${ }^{15}$.

Jednym z pilniejszych zadań publicystyki szlacheckiej było odniesienie się do sytuacji kobiet, gdyż elementy konstruujące wzorce ich ról społeczno-familijnych coraz wyraźniej kontrastowały z modernizującym się światem. Kształcenie i wychowanie szlachcianek zmierzało bowiem do przygotowania ich do wypełniania obowiązków żon, matek i pań na włościach oraz dam pełniących funkcje reprezentacyjne $\mathrm{w}$ tzw. towarzystwie ${ }^{16}$. Z tego też względu edukacja córek szlacheckich zamykała się w maksymie ex omnibus aliquid, ex toto nihil była więc powierzchowna i ograniczona do tego, co z punktu widzenia stawianych przed nimi zadań było nieodzowne. Wykształcenie nie stanowiło zresztą nigdy elementu wiążącego się z habitusem szlacheckim, nie ono bowiem decydowało o pozycji i prestiżu. Te cechy wynikać miały z samej przynależności do pierwszego stanu w państwie, chociaż

${ }_{14}$ T. Nipperdey, dz. cyt., s. 77-78; H.-W. Wehler, Teoria..., s. 25.

15 Por.: M. Seelig, Der Kampf gegen die Moderne. Krisenwahrnehmung und -bewältigung im „Deutschen Adelsblatt” um 1900, w: Krisenwahrnehmungen in Deutschland um 1900. Zeitschriften als Foren der Umbruchszeit im wilhelminischen Reich, red. M. Grunewald, U. Puschner, Bern 2010, s. 451-476.

${ }^{16}$ M. Kubrova, dz. cyt., s. 109, 129; O. Wörner-Heil, dz. cyt., s. 13. 
w ciagu wieku XIX część szlachty niemieckiej zaczynała rozumieć, że w nowych czasach edukacja domowa to jednak za mało ${ }^{17}$. Pod koniec XIX i na początku XX w. w obliczu ubożenia wielu rodzin szlacheckich lepsze wykształcenie córek miało stać się magnesem przyciagającym potencjalnych kandydatów na mężów. Zarazem w przypadku pozostawania $\mathrm{w}$ stanie panieńskim zdobyta wiedza stwarzała tym kobietom szanse na samodzielne utrzymanie ${ }^{18}$. Mimo to, jak wskazują wyniki badań, ideał wychowawczy szlachcianki opierał wciąż na tych samych cnotach i cechach, które miały uczynić z niej odpowiedzialną matkę i panią na włościach, akceptująca całkowite poddanie się męskiej dominacji. Córkom szlacheckim nadal wpajano więc posłuszeństwo, uległość, skromność, przyzwoitość, zrozumienie zasad moralnych połączone z religijnościa, stanową (szlachecka) świadomośćc ${ }^{19}$, oznaczająca również dystans wobec niżej urodzonych, ale i obowiązi społeczne. Kształtowano przy tym ich charakter, wymagając odwagi, stanowczości, uczciwości i umiejętności wyrzeczenia się własnego „ja” w imię wyższych celów. Łączyła się z tym samokontrola, zwłaszcza panowanie nad emocjami i dobre maniery. Córkom szlacheckim zaszczepiano także troskę o wygląd zewnętrzny, zdrową cerę, właściwą postawę i sposób poruszania się. Ten komplet obowiązujących wzorów myślenia i zachowania majaccy tworzyć swoisty language of class był przyswajany poprzez wychowanie w kręgu familii i kształtowany przez codzienną praktykę. Umacniał bardzo istotną świadomość bycia częścią większej całości, tj. rodu i stanu mającego swoją znakomitą przeszłość oraz przekonanie o jedności kulturowej tak przecież zróżnicowanej niemieckiej szlachty ${ }^{20}$. Zachowanie owej jedności stało się szczególnie ważne w obliczu święcącej sukcesy w XIX w. kultury mieszczańskiej, która - chociaż w ograniczonym zakresie - przenikała również w szeregi „urodzonych” przyczyniając się do naruszenia wewnątrzstanowych kanonów.

Na łamach „Deutsches Adelsblatt” do wybuchu I wojny światowej kwestia kobieca pojawiała się kilkakrotnie, zarówno w pierwszych

${ }^{17}$ H. Reif, Westfälischer Adel 1770-1860. Vom Herrschaftsstand zur regionalen Elite, Göttingen 1979, s. 340-342.

18 O. Wörner-Heil, dz. cyt., s. 56, 127-128.

19 E. Conze, Adel und Moderne in Ostmitteleuropa. Überlegungen zur Systematisierung eines adelshistorischen Feldes zwischen Region, Nation und Europa, w: Adel in Schlesien, t. 1: Herrschaft - Kultur - Selbstdarstellung, red. J. Harasimowicz, M. Weber, München 2010, s. 331.

${ }^{20}$ M. Kubrova, dz. cyt., s. 110-115; M. Wienfort, dz. cyt., s. 122-123, 126-127; Ch. Diemel, Adelige Frauen im bürgerlichen Jahrhundert. Hofdamen, Stiftsdamen, Salondamen 1800-1870, Frankfurt/M 1998, s. 26-36. 
latach funkcjonowania periodyku, jak i na początku XX w. ${ }^{21} \mathrm{~W}$ warunkach przyspieszonej industrializacji wywołujacej coraz wyraźniejszy rozdźwięk między zmieniającą się rzeczywistością a utrwalonymi tradycja, wartościami i wzorami zachowań, z punktu widzenia tracącej dotychczasowa pozycję konserwatywnej szlachty zaistniała konieczność wskazania kobietom należącym do tego stanu źródeł zagrożeń i nakreślenia oczekiwanych od nich zachowań. Autorem kluczowych artykułów, które w kilku częściach ukazywały się na ten temat w roku 1884, 1887 i 1903 był Oldwig von Uechtritz (właściwie: Oldwig von Uechtritz und Steinkirch, urodzony w Dortmundzie w 1832, zmarły w Dreźnie w 1910 r.), oficer i konserwatywny publicysta, który należał zarówno do grona założycieli Stowarzyszenia Szlachty Niemieckiej, jak i jej organu prasowego. Inni, którzy podpisywali swoje artykuły, zabierając sporadycznie głos w tej sprawie, zwykle - tak jak hrabia von Haslingen - również byli członkami wspomnianej organizacji. Ten męski punkt widzenia uzupełniały też głosy kobiece związane ze środowiskiem konserwatywnej szlachty, tak jak miało to miejsce w przypadku Agnes von Reden, działaczki Ewangelicko-Niemieckiego Związku Kobiet (Deutsch-Evangelischer Frauen-Bund $)^{22}$.

Tym, co budziło największy niepokój był negatywny wpływ kapitalizmu, wszechobecnego kultu pieniądza i wszelkich przejawów nowoczesności na tradycyjne wartości i więzi, które kultywowane przez pokolenia stanowiły o odrębności i pozycji stanu. Materializm, oportunizm, upadek życia rodzinnego i panujących dotąd zasad postrzegano w kategoriach chorób, które nękały szlachtę, prowadząc do jej upadku. Ubolewano, nad tym, że kobiety pociagał luksus, świat salonów towarzyskich, wygodny styl życia w mieście. Nie chciały mieszkać na wsi, marzyły o tym, aby stać się światowymi damami, stąd też naśladowały modę i były zapatrzone w obcą kulturę, zwłaszcza angielską. W związku z tym nie wypełniały obowiązków stanowych, zanikała wśród nich pobożność, chrześcijańska moralność i duch szlachty niemieckiej, czemu

${ }^{21}$ O. von Uechtritz, Die deutsche Edelfrau und ihre Aufgabe in der Gegenwart, „Deutsches Adelsblatt” 2, 1884, s. 484-485, 494-496, 509-510, 519-521, 532-534, 543-545; tenże, Unsere Frauen in der Standes-Reform-Bewegung, „Deutsches Adelsblatt” 5, 1887, s. 381-382, 400-401, 420-421, 436-438; tenże, Die deutsche Edelfrau. Ein Sozial-Historisches Charakterbild. Vortrag, gehalten in der Landesabteilung Königreich Sachsen der Deutsche Adelsgenossenschaft am 7. Februar 1903, „Deutsches Adelsblatt" 21, 1903, s. 462-464, 478-481, 496-497, 510-513. Do kwestii kobiecej powrócono na łamach periodyku po I wojnie światowej.

22 S. Malinowski, Vom König..., s. 168. Część autorów nie podpisywała swoich artykułów lub posługiwała się inicjałami, których identyfikacja nie jest jednoznaczna. 
towarzyszyła ignorancja wobec własnej przeszłości, powierzchowność formy, której nie nasycała już żadna treśćc ${ }^{23}$. Postawy takie - w przekonaniu publicystów - łączyły się z nieodpowiednim do przynależności społecznej i pozycji towarzyskiej zachowaniem, czyli - jak to określano - brakiem taktu, co miało powodować osłabienie barier stanowych i zacieranie się prestiżu, jakim powinna cieszyć się szlachta. Co więcejw opinii piszących - o utrzymanie stanowych odrębności bardziej dbały kobiety pochodzenia mieszczańskiego, które za sprawą małżeństwa dostapiły nobilitacji, niż te wywodzące się ze starych rodów ${ }^{24}$. Skłonność do łatwego, wypełnionego zabawą i przyjemnościami życia, według anonimowego listu nadesłanego do redakcji tygodnika w 1897 r., miała charakteryzować postawę nie tylko panien na wydaniu, ale także mężatek. Te bowiem zamiast poświęcać czas domowi i rodzinie, chciały prowadzić taki sam styl życia, jak przed ślubem. Miały duże wymagania i oczekiwały, że mąż będzie spełniał ich wszystkie kaprysy, co dla wielu kawalerów miało być powodem odkładania decyzji o zawarciu małżeństwa właśnie ze względu na niemożność zapewnienia odpowiedniego poziomu życia przyszłej rodzinie ${ }^{25}$. Publikowane skargi dotyczyły też niechęci szlachcianek do wypełniania obowiązków domowych i skłonności do cedowania wszystkich spraw na służbę, począwszy od opieki nad dziećmi po decyzje dotyczące codziennego jadłospisu. Ganiony był zwłaszcza brak zaangażowania matek w wychowanie potomstwa. Opiekunki czy guwernantki, którym powierzano to zadanie nie były bowiem w stanie przekazać szlacheckich wzorów zachowań i sposobu myślenia, a przecież od ich wpojenia następnym generacjom zależała przyszłość szlachty ${ }^{26}$. Przy tej okazji, zwłaszcza w artykułach z ostatnich lat XIX i pierwszych XX w., odnaleźć można słowa ubolewania nad zakresem edukacji kobiet, który nie obejmuje wiedzy i umiejętności, jakimi powinny się one wykazać po zamążpójściu. Szlachcianki kształcone sa w oderwaniu od rzeczywistości. Jako przyszłe „światowe damy” rozwijają głównie swoje talenty artystyczne i nie uczą się niczego, co przygotowałoby teoretycznie i praktycznie do wykonywania takich prozaicznych zajęć codziennych, jak np.: gotowanie, pranie, czy cerowanie. Sytuacja ta - zdaniem publicysty - powodowała, że kobiety, chociaż dążyły do tego, aby jak najszybciej stanąć na ślubnym kobiercu, to jednak później były w małżeństwie nieszczęśliwe i unieszczęśliwiały tym

\footnotetext{
${ }^{23}$ O. von Uechtritz, Die deutsche Edelfrau und ihre..., s. 532.

24 Tamże, s. 520.

${ }^{25}$ [b.a.] Zur Frauenfrage, „Deutsches Adelsblatt” 15, 1897, s. 158.

${ }^{26}$ O. von Uechtritz, Die deutsche Edelfrau und ihre..., s. 533.
} 
samym swoich mężów, gdyż nie spełniały pokładanych w nich oczekiwań ${ }^{27}$. W pierwszych latach XX stulecia do szeregu argumentów wskazujących na niepraktyczny zakres kształcenia szlachcianek doszedł jeszcze jeden, mianowicie brak zawodu ${ }^{28}$. Kwestia ubożenia przedstawicieli stanu i konieczność pracy zarobkowej należących do niego kobiet występowała na łamach „Deutsches Adelsblatt” już wcześniej, ale z czasem pojawiło się przekonanie, że w takiej sytuacji jest coraz większe grono szlachcianek i tygodnik, w ramach stanowej solidarności, zaangażował się w różne formy niesienia im pomocy. Początkowo przede wszystkim szukano u czytelników zrozumienia dla tych kobiet, jako że praca nie mieściła się w kanonie atrybutów szlacheckości. Przy założeniu, że wykonywana profesja będzie odpowiednia do przynależności społecznej apelowano, aby dopuścić zarobkowanie szlachcianek, uznając je za konieczność życiową ${ }^{29}$. Później jednak, kiedy okazało się, że jest zbyt mało zawodów mogacych liczyć na stanową akceptację, „Deutsches Adelsblatt” podjął się poszukiwania i propagowania sposobów zarobkowania właściwych dla kobiet „urodzonych”30. Wówczas okazało się, że powierzchowne, niepraktyczne kształcenie dziewcząt znacznie zawężało ich możliwości pracy. Jak wskazywali publicyści sytuację pogarszało również to, że młode szlachcianki nie były przez matki wdrażane do żadnych zajęć domowych. Nie miały również pojęcia o tym, jakimi zasadami kieruje się świat, gdyż rodzice czynili wszystko, aby uchronić swoje córki przed zgubnym - jak sądzili - wpływem „wrogiego życia”. Takie wychowanie pod kloszem zwiększało dramatyzm sytuacji wówczas, gdy zabrakło najbliższych, nie było perspektyw na zamążpójście i kobieta musiała sama zadbać o siebie. W biurze pośrednictwa pracy okazywało się niekiedy, iż umiejętności jakimi dysponowała, odpowiadały jedynie tym zawartym w anonsach, poprzez które poszukiwano służących ${ }^{31}$. Według publicystów tygodnika przyczyną tej sytuacji był deficyt edukacyjny szlachcianek. Dotąd szlachta inwestowała przede wszystkim w kształcenie synów, wychodząc z założenia, że córki „i tak wyjdą za mąż”. W zmieniającym się świecie - jak twierdzili publicyści - nie było to już wcale takie oczywiste. Synowie zwykle nie mieli trudności ze znalezieniem odpowiedniego

27 [b.a.] Zur Frauenfrage..., s. 158.

${ }^{28}$ Frr v. M., Die adelige Frauen im Lebenskampf, „Deutsches Adelsblatt” 22, 1904, s. $831-833$.

${ }^{29}$ O. von Uechtritz, Die deutsche Edelfrau und ihre..., s. 544.

${ }^{30}$ O. Wörner-Heil, dz. cyt., s. 55-56.

31 v. B. H., Unsere Töchter, „Deutsches Adelsblatt” 27, 1909, s. 179-181; O. WörnerHeil, dz. cyt., s. 77-78, 85. 
zatrudnienia, natomiast los samotnej, niewykształconej szlachcianki był tragiczny ${ }^{32}$.

Zamieszane w „Deutsches Adelsblatt” krytyczne głosy na temat stylu życia, zachowań, preferowanych wartości, zasad edukacyjno-wychowawczych szlachcianek nie stanowiły jedynie wyrazu ubolewania nad „zepsuciem” wynikającym z wszechobecnego panowania nowoczesności. Co więcej, publicyści przestrzegali, by nie ograniczać się tylko do „wzdychania” za starymi, dobrymi czasami i opłakiwania upadającej tradycji. W obliczu szybkiego tempa zmian, które szły niczym „w siedmiomilowych butach”, szlachta nie mogła stać obojętna. Musiała na nowo zdefiniować istotę szlacheckości, uwzględniając nowe elementy będące wynikiem zachodzacych zmian, tak aby nie stać się jedynie reliktem przeszłości i nadal pozostawać na szczycie hierarchii społecznej. W myśl publicystów „Deutsches Adelsblatt” konserwatywna szlachta ucieleśniała bowiem esencję niemieckości i najwyższych moralnych wartości tkwiących w narodzie oraz wierności cesarzowi i państwu. Musiała więc stawić czoła nowoczesności, zreformować się jako stan: z jednej strony poprzez przypomnienie ciążących na niej obowiązków, z drugiej zaś - poprzez określenie zadań, jakie stawiaja przed „urodzonymi” nowe czasy ${ }^{33}$. W realizację tego programu włączone miały zostać również kobiety, którym nakreślono cały szereg zadań wpisujacych się w ruch odbudowy wewnętrznej stanu. Dotyczyły one postaw i zachowań szlachcianek na kilku płaszczyznach, które zgodnie z tradycyjnym porządkiem płci były im przypisane. Zreszta, przedefiniowanie roli i pozycji kobiety w społeczeństwie stanowiło element debat prasowych nie tylko w Niemczech, i nie tylko w odniesieniu do szlachty. To problem, który wyłonił się jako pochodna modernizacji i przemian cywilizacyjnych ${ }^{34}$. Z publikacji zamieszczanych na ten temat na przełomie XIX i XX w. we wspomnianym periodyku wyraźnie wyłania się katalog powinności szlachcianek jako żon, matek i pań na włościach, jak również - co należy uznać za symptom dokonujaccych się przeobrażeń - działaczek realizujących określoną misję w sferze publicznej.

${ }^{32}$ Graf v. Haslingen, Zentral-Hilfsverein der DAG, „Deutsches Adelsblatt” 32, 1914, s. 327-328.

${ }^{33}$ v. d. L.-W. Adel verpflichtet, „Deutsches Adelsblatt” 1, 1883, s. 115; O. von Uechtritz, Unsere Frauen..., s. 381.

34 Porównawczo dla ziem polskich zob.: M. Gawin, Spór o równouprawnienie kobiet (1864-1919), Warszawa 2015, s. 185-186 i nn. 


\section{Wzorzec żony}

Odbudowa życia rodzinnego opartego na tradycji stanowej i zasadach chrześcijańskich miała być podstawą odrodzenia i umocnienia moralnego szlachty w obliczu destrukcyjnego, kierującego się wyłącznie chęcią zysku kapitalizmu oraz kultu pieniądza. Dom, zgodnie z naturalnym - uznawanym przez konserwatystów za niepodważalny - porządkiem płci miał stanowić sferę dominacji kobiet. W związku z tym szlachcianka obarczona została odpowiedzialnością za utrwalanie na łonie rodziny odpowiednich form, zachowań i obyczajów właściwych dla tego stanu. Po zamążpójściu winna mieć decydujacy wpływ na życie wewnętrzne rodziny. Zwracano uwagę, że musi zadbać o to, aby dom był dla męża oazą spokoju, miejscem, gdzie może znaleźć wytchnienie po trudach związanych z jego działalnością czy praca w sferze publicznej, oazą dająca odpoczynek po „pędzie męskiego tworzenia”. W tej atmosferze ma odzyskać siły, wzmocnić swój świat wartości wystawiany na próbę $\mathrm{w}$ kontakcie $\mathrm{z}$ królującym wszędzie materializmem. Mąż musi mieć w żonie oparcie, ma ona zawsze stać przy jego boku, wówczas gdy wypełnia on swoje obowiązki wobec kraju lub te wynikające z jego powinności stanowych. Równocześnie małżonka winna być powiernikiem jego trosk, kłopotów i cichym doradca. Ona także, stojąc na straży szlacheckiej odrębności, ma być wyrocznią w sprawach zasad, taktu i właściwego zachowania wynikającego nie tylko z przynależności społecznej, ale także chrześcijańskiej moralności ${ }^{35}$. Z tego też względu powinna być bardzo dobrze zaznajomiona $\mathrm{z}$ obyczajami i tradycja szlachecka, jak również ze wszystkimi socjalnymi zobowiązaniami łączącymi się z przynależnością do grona „urodzonych” (jeżeli natomiast wywodzi się z mieszczaństwa, zadaniem męża jest przygotować żonę do ich wypełniania). Stąd też musi studiować leksykony i genealogie szlacheckie, znać przeszłość rodu, jak i całego stanu. Temu między innymi powinna poświęcać wolny czas, nie zaś życiu salonowemu czy pławieniu się w luksusie. W myśl tych przekonań o szlacheckości nie świadczy szczycenie się tytułem i herbem, a wypełnianie wiążących się z nią obowiązków. Spędzanie czasu na rozwijaniu swoich zainteresowań artystycznych z perspektywy publicystów „Deutsches Adelsblatt” niczemu nie służy, jest jałowe, ponieważ szlachcianka powinna bez reszty poświęcić się mężowi, dzieciom i innym swoim powinnościom. Konsumpcjonizmowi nowych czasów musi mieć odwage przeciwstawić

${ }^{35}$ O. von Uechtritz, Die deutsche Edelfrau und ihre..., s. 520; tenże, Unsere Frauen..., s. 381. 
cnoty prostoty, oszczędności i skromności i w ten sposób walczyć o zniwelowanie negatywnych skutków nowoczesności oraz odrodzenie niemiecko-chrześcijańskiego ducha szlachty ${ }^{36}$. Nie może też ulegać licznym w prasie głosom, które propaguja przedefiniowanie zadań kobiet w ramach rozwiązania tzw. kwestii kobiecej. W opinii tygodnika emancypacja niszczy rodzinę, święty porządek społeczny i narusza zasady, którym ma być wierna szlachta. Niezłomne stanowisko kobiet z tego stanu ma być tarcza, o którą będą kruszyć się wszystkie destrukcyjne prądy nowych czasów ${ }^{37}$.

\section{Wzorzec matki}

Uczynienie z kobiet strażniczek ducha stanowego, tradycji i moralności powodowało, iż w myśl publikacji zamieszczanych na łamach „Deutsches Adelsblatt” jako matki miały się one stać odpowiedzialne za wyposażenie swoich dzieci we wszystkie elementy szlacheckiej świadomości. W związku z tym nie powinny się wyręczać opiekunkami czy domowymi nauczycielami, ponieważ w ten sposób ów cel nie zostanie zrealizowany. Tylko bezpośrednie zaangażowanie się matek w opiekę nad dziećmi mogło dać oczekiwane rezultaty. Wychowanie powinno opierać się na tradycyjnych cnotach szlacheckich: prostocie, skromności, zdyscyplinowaniu, umacniać pobożność i niemieckośćc ${ }^{38}$. Z tego ostatniego powodu zalecano przykładanie szczególnej wagi do imion nadawanych dzieciom, przestrzegając przed naśladowaniem mody na te obco brzmiące. Pomoca w kształtowaniu stanowej świadomości miały być galerie przodków zajmujacce poczesne miejsce w siedzibach szlacheckich, zdobienia i dekoracje zawierajace motywy heraldyczne, epitafia w kościołach. Cechy te winna umacniać również odpowiednia lektura dobierana pod okiem matki czy też rozmowy z przedstawicielami starszego pokolenia, seniorami rodów. W przypadku synów kształcących się poza domem należało zwracać uwagę na niwelowanie - jak twierdzono - negatywnego wpływu szkoły na wartości szlacheckie. Dom miał być więc miejscem, w którym tradycję i formy szlacheckie należało pielęgnować ze szczególna gorliwościa, ale tak, aby jednocześnie uniknacc fałszywej dumy, próżności czy zarozumiałości.

${ }^{36}$ Tenże, Die deutsche Edelfrau und ihre..., s. 532, 544.

37 Tenże, Unsere Frauen..., s. 381; [b.a.] Zur Frauenfrage..., s. 157.

${ }_{38}$ Por.: M. Borzyszkowska-Szewczyk, Pamięć dla przyszłości. Literatura wspomnieniowa potomków szlachty pruskiej z Pomorza Zachodniego i z Prus Wschodnich po 1945 roku, Wrocław 2009, s. 99-107. 
Matczyna pedagogika powinna opierać się na łagodnym napominaniu, tłumaczeniu przez odwoływanie się do przykładów, stwarzaniu różnych sytuacji, za sprawą których dzieci zrozumiałyby, co jest dla nich właściwe $\mathrm{z}$ racji pochodzenia. Poglądowe nauczanie miało wpłynać przede wszystkim na ich emocje i uczucia, jak również zapobiec wyrobieniu fałszywego mniemania o sobie. W publikacjach podkreślono bowiem, że wcześniej szlachta była wyobcowana, żyła ponad resztą społeczeństwa, teraz natomiast ma mu służyć poprzez krzewienie tradycyjnych wartości. Wychowanie pod okiem matki miało więc również przygotować synów do wykonywania odpowiedniego zawodu, który umożliwiałby im realizację tej społecznej misji3i ${ }^{3}$. Szczególnie dużo czasu matki powinny poświęcić także córkom, gdyż to one będą odpowiedzialne za tożsamość stanową następnego pokolenia. Ważne miejsce w ich wychowaniu musza zatem zajać nie tylko takt, dobre maniery, ale także świadomość przeszłości i tradycji rodu ${ }^{40}$. Na matkach spoczywa również obowiąek przygotowania córek do wejścia w życie towarzyskie i zapewnienia im odpowiedniej pozycji. W związku z tym, wykorzystując wiedzę na temat koligacji, powiązań rodzinnych i towarzyskich, muszą się one starać, aby bywały w odpowiednim gronie. Matki powinny również czuwać nad sposobami spędzania wolnego czasu przez swoje córki, tak by wypełniały wolne chwile pożytecznymi zajęciami. Od ostatnich lat XIX w. coraz wyraźniejszy stał się również głos zwracający matkom uwagę na dopilnowanie przygotowania dziewcząt do prowadzenia gospodarstwa domowego, co miało się też wiązać z posyłaniem ich do powstających wówczas szkół o takim profilu. Tam mogłyby zdobyć nowoczesną wiedzę z zakresu teorii żywienia, prowadzenia rachunków, opieki nad chorymi, udzielania pierwszej pomocy, jak również doskonalić swoje umiejętności z zakresu różnych pożytecznych prac domowych ${ }^{41}$. Matki powinny zrozumieć, że takie wykształcenie - jak podkreślaja publicyści tygodnika - jest we współczesnym, zmieniającym się świecie koniecznościa, ale i podstawą szczęśliwego małżeństwa ${ }^{42}$. Co więcej, to kapitał, który stwarza szansę na samodzielne utrzymanie się, jeżeli w przyszłości okaże się, że nie będą miały zabezpieczenia finansowego.

${ }^{39}$ O. von Uechtritz, Unsere Frauen..., s. 420-421.

${ }^{40}$ Tenże, Die deutsche Edelfrau und ihre..., s. 532.

${ }^{41}$ [b.a.] Ein Institut zur Ausbildung von Töchtern der höheren Stände für das practische Leben, „Deutsches Adelsblatt” 14, 1896, s. 934; [b.a.] Zur Frauenfrage..., s. 157-158; v. B., Zur „Frauenfrage”, „Deutsches Adelsblatt” 19, 1901, s. 822-823; A. von Reden, Zur modernen Frauenbewegung. Eine Erwiderung an C. v C., „Deutsches Adelsblatt" 16, 1905, s. 490-491; Graf von Haslingen, Zentral-Hilfsverein ..., s. 327-328.

${ }^{42}$ [b.a.] Zur Frauenfrage..., s. 158. 
Ubożenie szlachty stawia bowiem w takiej sytuacji coraz więcej kobiet z predykatem „von” przed nazwiskiem, zaś fachowe wykształcenie z zakresu prowadzenia gospodarstwa domowego stwarza im szansę na znalezienie „stanowo odpowiedniego” zatrudnienia. Matki musza być więc świadome, że edukacja tego typu jest wyrazem najwyższej troski o przyszłość córek. Zalecano nawet, aby w rodzinie kształcenie dziewcząt - zwłaszcza w tym kierunku - uważać za ważniejsze niż kształcenie chłopców. Twierdzono bowiem, że zubożałemu, niewyedukowanemu szlachcicowi łatwiej jest znaleźć odpowiednie dla niego płatne zajęcie niż zubożałej, nieposiadającej żadnego zawodu szlachciance ${ }^{43}$.

\section{Wzorzec szlachcianki: pani na włościach}

Publicyści „Deutsches Adelsblatt” jednoznacznie wskazywali na naturalne powiązanie szlachty ze wsia. Mimo zachodzacych zmian opowiadali się za utrzymaniem stosunków patriarchalnych określających relacje szlachty z ludnością chłopską ${ }^{44}$. W nowych czasach miały one wiązać się nie tylko z kontynuowaniem realizacji zadań opiekuńczych, ale z misja wychowawcza. Polegać ona miała na umacnianiu wśród mieszkańców wsi konserwatywnych wartości, tradycji, przywiązania do monarchii, chrześcijańskiej moralności w obliczu destrukcyjnego pod tym względem wpływu nowoczesności. W urzeczywistnianie tego programu włączone zostały „panie na włościach”, które zresztą zgodnie z tradycyjnym katalogiem powinności szlachcianek zamieszkałych na agrarnym Wschodzie Niemiec miały troszczyć się o chłopów mieszkających w ich dobrach ${ }^{45}$. W wypowiedziach zamieszczanych na łamach „Deutsches Adelsblatt” podkreślano jednak, że te socjalne obowiązi były coraz częściej ignorowane, a wypełnianie ich uważane było przecież za immanentną cechę szlachectwa. Co więcej, o przynależności do „urodzonych” nie decydował predykat „von” przed nazwiskiem, ale właśnie owa misja edukacyjno-wychowawcza wśród ludu. Bez niej kobiety „dekorowały się pustym aparatem stanowym” pozbawionym jakichkolwiek treści. W wypowiedziach zamieszczanych w tygodniku nie brakowało zreszta wypowiedzi na temat zmian ustrojowych wsi. Pojawiaja się sformułowania bezpośrednio wskazujące na konieczność powrotu

${ }^{43}$ [b.a.] Ein Institut zur Ausbildung..., s. 934; Graf v. Haslingen, Zentral-Hilfsverein..., s. 327-328.

${ }^{44}$ v. d. L.-W., „Adel verpflichtet”..., s. 115.

${ }^{45}$ O. von Uechtritz, Unsere Frauen..., s. 401. 
do historycznej, uważanej za naturalną feudalnej zależności chłopów od szlachty. Na tych obszarach, gdzie jeszcze pozostały jakieś formy podległości, kobiety powinny przykładać szczególną wagę do petryfikowania dotychczasowych stosunków. Z opieki nad mieszkańcami wsi nie zwalniało ich zreszta żadne ustawodawstwo uwłaszczeniowe, gdyż stanowiła ona ich ponadczasowy obowiązek ${ }^{46}$. To misja niezależna od zachodzacych zmian, a nie forma działalności dobroczynnej. Nie chodzi w niej bowiem tylko o materialna pomoc, ale przede wszystkim o kształtowanie świata wartości ludności chłopskiej. Nie moga więc jej zaniedbać, ale jak najszybciej się zaangażować, by nie doszło do zmian mentalnych mieszkańców wsi. Tygodnik zalecał również szlachciankom współpracę na tym polu z miejscowym duchowieństwem oraz powoływanie do życia stowarzyszeń o profilu opiekuńczo-wychowawczym ${ }^{47}$. Niezależnie od tego panie na włościach miały czuwać nad całym gospodarstwem domowym, samodzielnie wykonywać szereg prac, żyć skromnie, oszczędnie i z prostota, przeciwstawiając się w ten sposób materializmowi i modzie na luksus, rozpowszechnianym przez kulturę miejska.

\section{Wzorzec obecności w sferze publicznej}

Publicyści „Deutsches Adelsblatt” kreśląc kompleksowo zadania szlachcianek w nowym, industrialnym świecie, nie pominęli też i tych, które łączyły się ze sferą publiczna. Oczywiście, nie kwestionowano tradycyjnych obszarów aktywności kobiet poza domem, a więc przede wszystkim działalności dobroczynnej ${ }^{48}$, która w obliczu mocarstwowej polityki Niemiec obejmować miała także pomoc potrzebującym znajdującym się poza granicami kraju oraz na innych kontynentach ${ }^{49}$. Co więcej, zachęcano do niej, jako że powiązana była ściśle z obowiązkami socjalnymi szlachty. Novum stanowiło jednak zdefiniowanie kolejnego, odmiennego od dotychczasowych kierunku działań, mianowicie wspieranie zubożałej szlachty, zwłaszcza kobiet, które z różnych względów nie miały środków na utrzymanie ${ }^{50}$. Związki rodowe (Familienverbände) oraz stowarzyszenia szlacheckie coraz częściej (w ramach samopomocy

${ }^{46}$ R. Brunner, Landadeliger Alltag und primäre Sozialisation in Ostelbien am Ende des 19. Jahrhunderts, „Zeitschrift für Geschichtswissenschaft” 39, 1991, 10, s. $1008-1009$.

47 O. von Uechtritz, Die deutsche Edelfrau und ihre..., s. 520, 532.

48 Tamże, s. 543.

49 Tamże, s. 544.

${ }^{50}$ O. von Uechtritz, Unsere Frauen..., s. 421, 437. 
wewnątrzstanowej) powoływały do życia fundusze opiekuńcze, a nawet zakłady o takim charakterze ${ }^{51}$. Tygodnik postulował otworzenie przed kobietami zjazdów i stowarzyszeń szlacheckich, z których były z reguły ze względu na płeć wykluczone i włączenie ich w realizację różnych inicjatyw opiekuńczych ${ }^{52}$. Inicjatywy te - co istotne - nie oscylowały wyłącznie w kręgu tradycyjnych form pomocy, ale również miały za zadanie wspierać szlachcianki poszukujące zatrudnienia. Ta ostatnia kwestia była zresztą szeroko dyskutowania na łamach „Deutsches Adelsblatt” i odegrała istotną rolę w zakresie przedefiniowania obszarów obecności szlachcianek w sferze publicznej. Wypowiedzi na ten temat początkowo publikowano sporadycznie, ale z czasem poruszano tę sprawę coraz częściej wskazując, iż należy dopuścić możliwość pracy córek szlacheckich, ale tylko wówczas, jeżeli wymaga tego ich sytuacja ekonomiczna. Kluczowe znaczenie miał więc wybór profesji, gdyż musiała ona należeć do kręgu tych, które mogły liczyć na stanową akceptację $e^{53}$. Chcąc pomóc czytelniczkom w wyborze zawodu odpowiedniego do pochodzenia społecznego, w kolejnych artykułach wskazywano na szereg właściwych dla nich zajęć, które najczęściej wiązały się z profesjonalizacją i przeniesieniem w sferę publiczną tych czynności, które - zgodnie z tradycyjnym podziałem ról w rodzinie szlacheckiej - miały wykonywać w domu, np. guwernantka, dama do towarzystwa, opiekunka, wychowawczyni ${ }^{54}$. Towarzyszyły temu wspomniane wyżej postulaty dotyczące edukacji zawodowej córek szlacheckich majacej m.in. przygotować je do sytuacji, w której będą musiały samodzielnie się utrzymywać. Na podstawie wypowiedzi publicystów tygodnika można więc przyjąć, że na początku XX w. dopuszczono pracę zarobkową szlachcianek, ale wyłącznie samotnych i tylko wówczas, gdy stanowiła ona konieczność życiową oraz wiązała się z wykonywaniem zawodu uznanego za odpowiedni.

Kolejna, nową formą aktywności szlachcianek, którą również należy uznać za skutek procesów modernizacji, była coraz bardziej dostrzegalna ich obecność w stowarzyszeniach związanych z ruchem kobiecym. Publicyści, zwłaszcza w pierwszych latach funkcjonowania „Deutsches Adelsblatt", bardzo krytycznie wypowiadali się na temat postulatów

${ }^{51}$ C. Boysen, Frauenfrage und Adelsgenossenschaft, „Deutsches Adelsblatt” 22, 1904, s. 344; W. Stępiński, Procesy integracyjne wobrębie rodów szlacheckich na Pomorzu Zachodnim, w: Rodzina pomorska, red. J. Borzyszkowski, Gdańsk 1999, s. 170-189.

${ }^{52}$ O. v. Uechtritz, Die deutsche Edelfrau und ihre ..., s. 544.

${ }^{53}$ Kwestia ta została omówiona w pracy: O. Wörner-Heil, dz. cyt., s. 52-59 i nn.

${ }^{54}$ [b.a.] Die materielle Grundlage des Adels, „Deutsches Adelsblatt” 5, 1887, s. 240; J.M. Singer, dz. cyt., s. 157, 334. 
związanych z emancypacją kobiet, sądząc, że jest to ruch, w wyniku którego chca one „przemienić się” w mężczyzn. W kręgach szlacheckich (i nie tylko) nierówność płci uznawano bowiem za naturalny, boski porządek rzeczy i uważano, że poprzez dążenie do zmian w tym zakresie kobiety narażają na szwank funkcjonowanie rodziny ${ }^{55}$. W Niemczech rozwinęły się jednak różne nurty ruchu, w tym konserwatywny, którego zadaniem było pielęgnowanie przywiązania do monarchii, umacnianie postawy patriotycznej oraz dążenie do lepszego przygotowania kobiet do wypełniania tradycyjnych ról społecznych ${ }^{56}$. W późniejszych publikacjach „Deutsches Adelsblatt” zwraca więc uwagę, że powstawanie stowarzyszeń o konserwatywnym programie społecznym ma na celu naprawę szkód, jakie wyrządza liberalny ruch kobiecy, który uważano za niezdrowy oraz nienaturalny, propagowany za pośrednictwem prasy przez emancypantki „trzymające cygaro" ${ }^{57}$. W ocenie tygodnika źródłem dążeń do równouprawnienia kobiet były ich problemy socjalne. By więc rozwiązać je wśród szlachcianek i tym samym zmniejszyć podatność na propagandę ruchu, „Deutsches Adelsblatt” włączył się w akcję informacyjna, która miała na celu wskazanie im różnych form pomocy oraz możliwości zarobkowania inicjowanych m.in. przez Stowarzyszenie Szlachty Niemieckiej ${ }^{58}$. Oprócz tego jednak stopniowo kształtowało się przyzwolenie na aktywność szlachcianek w stowarzyszeniach, które nie negowały tradycyjnego porządku społecznego. Większość kobiet jak podkreślano - nie chciała zmian w tym zakresie i uważała, że ich obowiązkiem jest służenie mężowi i rodzinie ${ }^{59}$. Wśród stowarzyszeń, do których zaakceptowania przekonywano czytelników „Deutsches Adelsblatt” znajdowały się niewymieniane z nazwy wszystkie organizacje odrzucające radykalne hasła, zwłaszcza o charakterze wyznaniowym, stowarzyszenia działające na rzecz poprawy warunków życia i pracy oraz umocnienia moralnego kobiet ze wszystkich warstw społecznych ${ }^{60}$.

${ }_{55}$ O. von Uechtritz, Unsere Frauen..., s. 381; v. B., Zur „Frauenfrage”..., s. 822823. Stosunek konserwatystów do ruchu kobiecego ilustrować może notatka na temat światowego kongresu kobiet, który miał miejsce w Berlinie w 1896 r., opublikowana na łamach „Deutsches Adelsblatt”. Wydarzenie to zostało określone dosadnie jako „światowy kongres głupoty” i świadectwo upadku „naszej sławnej kultury”; O. Wörner-Heil, dz. cyt., s. 79.

56 A. Süchting-Hänger, Das „Gewissen der Nation”. Nationales Engagement und politisches Handeln konservativer Frauenorganisationen 1900-1937, Düsseldorf 2002, s. $19-89$.

57 O. von Uechtritz, Unsere Frauen..., s. 381.

58 C. Boysen, Frauenfrage..., s. 361.

59 [b.a.] Zur Frauenfrage..., s. 157.

60 A. von Reden, Zur modernen ..., s. 490-491. 
Tym samym aktywność w stowarzyszeniach konserwatywnego ruchu kobiecego zyskiwała status nowego elementu we wzorcu osobowym niemieckiej szlachcianki przełomu XIX i XX w.

Publikacje na łamach „Deutsches Adelsblatt” dotyczące zadań i roli szlachcianek stanowia - jak już wyżej wspomniano - element szerszego programu reformy wewnętrznej stanu, mającej ocalić i umocnić tradycyjne wartości stanowiące podstawę szlacheckiej tożsamości przede wszystkim w sferze mentalności oraz zachowań regulujących życie codzienne. To reakcja na kryzys modernizacyjny, czyli obserwowaną na co dzień niezgodność między tym, co stanowiło wyraz postępu, $\mathrm{np}$. w nastawionej na zysk i unowocześniającej się gospodarce wiejskiej (m.in. nawozy sztuczne, maszyny rolnicze, przemysł wiejski) a „tradycyjnymi wyobrażeniami o wartościach i wzorcach zachowań, osadzonych przecież głęboko w świecie preindustrialnym. Skutkowało to niepewnością statusu i pełnymi obaw przeczuciami dotyczącymi przyszłości stanu $^{61}$. W wymiarze psychicznym kryzys modernizacyjny zrodził kryzys nowoczesności, który z kolei należy rozumieć jako „problem wyobcowania, trudność uporania się z różnorodnością i zmianą ról [...], zachowania stabilności i tożsamości w warunkach zmiany [...]"62. W tej sytuacji szlachcie coraz trudniej było więc „być soba”. Środki symboliczne, które czerpała z kultury i tradycji nie pozwalały jej na jednoznaczne stwierdzenie, że jest częścią świata, w którym żyje. Jednak owa tradycja i kultura miały stać się podstawą definiowania siebie na nowo jako stanu, gdyż umocnienie wartości konserwatywnych postrzegano jako drogę do odrodzenia. W tej sytuacji zestaw pożądanych zachowań szlachcianek miał odegrać kluczową rolę, gdyż to właśnie im powierzono odpowiedzialne zadania utwierdzenia, krzewienia i przekazania następnym pokoleniom niemiecko-chrześcijańskiej tradycji i ducha stanowego $^{63}$. Warto podkreślić, iż w prezentowanych na łamach „Deutsches Adelsblatt" przekonaniach dotyczących ról społeczno-familijnych szlachcianek można odnaleźć te same argumenty, którymi posługiwali się nie tylko w Niemczech zwolennicy utrzymania dotychczasowego porządku płci w trwającym równolegle dyskursie na temat równouprawnienia kobiet ${ }^{64}$. Cechy majace ukształtować zachowania szlachcianek

${ }_{61}$ T. Nipperdey, dz. cyt., s. 87.

62 Tamże, s. 86.

${ }^{63}$ Podobne podejście do zadań kobiet mieli również i inni nacjonaliści, również na ziemiach polskich; zob.: M. Gawin, dz. cyt., s. 223-225.

${ }^{64}$ Zob.: U. Frevert, „Unser Staat ist männlicher Geschlechts”. Zur politischen Topographie der Geschlechter vom 18. bis frühen 20. Jahrhundert, w: taż, „Mann und Weib, und Weib und Mann”. Geschlechter-Differenzen in der Moderne, München 
nie stanowiły jednak wyłącznie katalogu postaw, które w dużej mierze można nazwać antytezą nowoczesności. Mamy bowiem w tym przypadku klasyczny przykład sytuacji, w której tradycja i nowoczesność nie stoją naprzeciw siebie, konkurując o zawłaszczenie intelektualnego podłoża podejmowanych działań ${ }^{65}$. Siła wpływu niektórych elementów nowoczesności przemodelowała bowiem dotychczasowe pojmowanie wzorca niemieckiej szlachcianki. Szlachta zakotwiczona głęboko $\mathrm{w}$ tradycyjnym porząlku społecznym gwarantujacym zachowanie tożsamości - zgodnie z koncepcją uczennicy Pierre'a Bourdieu Monique de Saint Martin $^{66}$ - absorbowała, ale na własnych warunkach tylko pewne cechy mieszczańskiego wzorca nowoczesnej kobiety, takie jak: edukacja, praca zarobkowa oraz zwiększenie zakresu aktywności w sferze publicznej. Na początku XX w. „Deutsches Adelsblatt” staje się orędownikiem nowych wzorów myślenia, które miały pozwolić „oswoić” nowoczesność poprzez zintegrowanie pewnych jej elementów z konserwatywną wizja zadań i roli kobiet. W ten sposób industrializacja i wszystkie zapoczątkowane przez nia zmiany gospodarcze i społeczne wpłynęły na sformułowanie nowych treści, które miały się odtąd wiązać ze wzorcem nowoczesnej niemieckiej szlachcianki (moderne Edelfrau) ${ }^{67}$. Wzorzec ten jednak, przed wybuchem I wojny światowej, zwłaszcza w kontekście zadań szlachcianek jako pań na włościach, przyswoił także elementy, które nie były wystarczajacco dobitnie podkreślane na łamach „Deutsches Adelsblatt”. Mianowicie, w kręgach związanych ze stowarzyszeniami konserwatywnego ruchu kobiecego (m.in. Patriotycznym Stowarzyszeniem Kobiet ${ }^{68}$, Vaterländische Frauenverein), a zwłaszcza wokół powstałego w 1896 r. z inicjatywy Idy von Kortzfleisch stowarzyszenia na rzecz organizacji szkół gospodarczych dla kobiet z obszarów wiejskich (Verein zur Errichting wirtschftlicher Frauenschulen auf dem Lande), od 1913 r. funkcjonującego pod nazwa „Związek Reifenstein” (Reifensteiner Verband) wypracowano model świadomej politycznie kobiety. Łączył

1995, s. 61-132. Szerzej: U. Planert, Antifeminismus im Kaiserreich: Diskurs, soziale Formation und politische Mentalität, Göttingen 1998, s. 20-32 i nn.

${ }^{65}$ Por.: T. Kizwalter, Procesy modernizacji a emancypacja kobiet na ziemiach polskich w XIX wieku, w: Kobieta i społeczeństwo na ziemiach polskich w XIX wieku, red. A. Żarnowska, A. Szwarc, Warszawa 1995, s. 6-7.

${ }^{66}$ R. Smoczyński, T. Zarycki, Wspótczesne polskie elity postszlacheckie w kontekście europejskim, „Kultura i Społeczeństwo” 2012, 1, s. 266-267.

${ }^{67}$ O. von Uechtritz, Unsere Frauen..., s. 401.

${ }^{68}$ A. Süchting-Hänger, „Gleichgroße mut'ge Helferinnen” in der weiblichen Gegenwelt: Der Vaterländische Frauenverein und die Politisierung konservativer Frauen 1890-1914, w: Nation, Politik und Geschlecht: Frauenbewegungen und Nationalismus in der Moderne, red. U. Planert, Frankfurt a. M 2000, s. 131-146. 
się on z przekonaniem, że poprzez odpowiednie wykształcenie i prowadzoną działalność może ona manifestować swój patriotyzm i współdziałać na rzecz budowy potęgi cesarstwa. Aktywność kobiet zyskiwała w ten sposób znamiona służby narodowej i prowadziła do głębokiej identyfikacji z celami politycznymi wilhelmińskich Niemiec. Szczególną rolę na obszarach wiejskich miały odegrać kobiety wykształcone z szkołach gospodarstwa domowego, gdzie edukacja obejmowała zapoznanie się z najnowszymi osiagnięciami nauki i techniki wykorzystywanymi $\mathrm{w}$ prawidłowym i racjonalnym prowadzeniu gospodarstwa domowego. W ten sposób po zakończeniu nauki stawały się one koryfeuszkami postępu na wsi, a przed zamążpójściem mogły pracować np. jako zarządczynie gospodarstwa domowego w majątkach czy ochmistrzynie w placówkach edukacyjno-wychowawczych ${ }^{69}$. Wymiar patriotyczny kształcenia w szkołach gospodarczych znakomicie łączył się z misja opiekuńczo-wychowawcza pań na włościach i tym samym jeszcze przed 1914 r. zyskał on status elementu wpisującego się we wzorzec nowoczesnej szlachcianki. W ten sposób modernizacja manifestujacca się na wsi m.in. przez stosowanie nowych metod produkcji rolnej czy hodowli lub mechanizację gospodarstw została po raz kolejny połączona z tradycją i posłużyła do umocnienia wpływów szlachty na obszarach wiejskich.

Problematyka ta wpisuje się więc w sformułowane przez Hansa-Ulricha Wehlera pojęcie „modernizacji defensywnej”, które oddaje charakterystyczny dla Niemiec mariaż tradycji i nowoczesności. Nowoczesności, której elementy wprowadzane pod kontrola i w ograniczonym zakresie, przemodelowane według własnych potrzeb miały służyć umocnieniu konserwatywnego porządku społecznego. Podobną strategię działania obserwować można także wśród arystokracji angielskiej oraz - choć w nieco innej formie - także u pozbawionej wpływów politycznych szlachty francuskiej ${ }^{70}$. W przypadku niemieckim jednak mariaż ten zrodził również nowy wzorzec szlachcianki. Nie oznacza to bynajmniej, iż odbiegał on zasadniczo od wcześniejszego. Jego dekonstrukcja przeprowadzona na łamach „Deutsches Adelsblatt”, wskazanie licznych rozbieżności między praktyką a oczekiwaniami i obowiązkami szlachcianek zdiagnozowały, gdzie tkwią słabości. Brak zrozumienia tego, jakie konsekwencje niesie ze sobą przynależność do szlachty, pokusa wygodnego

${ }^{69}$ Kwestie te analizuje O. Wörner-Heil, dz. cyt., s. 157-160, 169-176.

${ }^{70}$ M. Malatesta, The Landed Aristocracy during the Nineteenth and Early Twentieth Centuries, w: The European Way: European Societies in the $19^{\text {th }}$ and $20^{\text {th }}$ Centuries, red. H. Kaelble, New York-Oxford 2004, s. 56-61. Na temat odmiennych dróg rozwojowych szlachty europejskiej zob.: J. Osterhammel, dz. cyt., s. 997-999. 
życia, uleganie materializmowi i zepsuciu, którego siedliskiem w opinii publicystów było miasto ${ }^{71}$ to główne oskarżenia formułowane pod adresem kobiet. Przemodelowany wzorzec szlachcianki nie tylko więc przywoływał siatkę ich tradycyjnych powinności, ale wplatał do niej nowe elementy (np. lepsza edukacja jako profesjonale przygotowanie się do roli żony, matki i pani na włościach oraz zabezpieczenie przed deklasacją na wypadek braku kandydata na męża), łącząc je przy tym w harmonijną całość. Co więcej, konstrukcji tej towarzyszył kontekst stanowo-nacjonalistyczny, który waloryzował stare cnoty, nasycał je dodatkowa treścią dowartościowująca kobiety, czyniąc z nich wykonawczynie specjalnej misji. Od jej powodzenia zależała - jak sądzono - nie tylko przyszłość szlachty jako stanu, ale także i całej Rzeszy.

\section{Bibliografia}

\section{Źródła}

[b.a.], Ein Institut zur Ausbildung von Töchtern der höheren Stände für das practische Leben, „Deutsches Adelsblatt” 14, 1896.

[b.a.], Die materielle Grundlage des Adels, „Deutsches Adelsblatt” 5, 1887.

[b.a.], Zur Frauenfrage, „Deutsches Adelsblatt” 15, 1897.

B. H. v., Unsere Töchter, „Deutsches Adelsblatt” 27, 1909.

B. v., Zur „Frauenfrage”, „Deutsches Adelsblatt” 19, 1901.

Boysen C., Frauenfrage und Adelsgenossenschaft, „Deutsches Adelsblatt” 22, 1904.

Haslingen Graf v., Zentral-Hilfsverein der DAG, „Deutsches Adelsblatt” 32, 1914.

L.-W. v. d., „Adel verpflichtet”, „Deutsches Adelsblatt” 1, 1883.

M. Frr v., Die adelige Frauen im Lebenskampf, „Deutsches Adelsblatt” 22, 1904.

Reden A. v., Zur modernen Frauenbewegung. Eine Erwiderung an C. v. C., „Deutsches Adelsblatt” 16, 1905.

Uechtritz O. v., Die deutsche Edelfrau und ihre Aufgabe in der Gegenwart, „Deutsches Adelsblatt” 2, 1884.

Uechtritz O. v., Die deutsche Edelfrau. Ein Sozial-Historisches Charakterbild. Vortrag, gehalten in der Landesabteilung Königreich Sachsen der Deutsche Adelsgenossenschaft am 7. Februar 1903, „Deutsches Adelsblatt” 21, 1903.

Uechtritz O. v., Unsere Frauen in der Standes-Reform-Bewegung, „Deutsches Adelsblatt” 5, 1887.

${ }^{11}$ Dychotomię wieś - miasto w publicystyce zachodnioeuropejskiej XIX w. omawia J. Jedlicki, Proces przeciwko miastu, w: tenże, Świat zwyrodniały Lęki i wyroki krytyków nowoczesności, Warszawa 2000, s. 63-82. 


\section{Opracowania}

Beck H., Konservative Politik und Modernisierung in Preußen, w: Pommern im 19. Jahrhundert. Staatliche und gesellschaftliche Entwicklung in vergleichender Perspektive, red. T. Stamm-Kuhlmann, Köln-Weimar-Wien 2007.

Borzyszkowska-Szewczyk M., Pamięć dla przyszłości. Literatura wspomnieniowa potomków szlachty pruskiej z Pomorza Zachodniego i z Prus Wschodnich po 1945 roku, Wrocław 2009.

Brunner R., Landadeliger Alltag und primäre Sozialisation in Ostelbien am Ende des 19. Jahrhunderts, „Zeitschrift für Geschichtswissenschaft” 39, 1991, 10.

Conrad H., Stand und Konfession. Der Verein der katholischen Edelleute. Teil 1: Die Jahre 1857-1918. „Westfälische Zeitschrift - Zeitschrift für vaterländische Geschichte und Altertumskunde" 158, 2008.

Diemel Ch., Adelige Frauen im bürgerlichen Jahrhundert. Hofdamen, Stiftsdamen, Salondamen 1800-1870, Frankfurt a. M. 1998.

Elias N., Rozważania o Niemcach, Poznań 1996.

Frevert U., „Unser Staat ist männlicher Geschlechts”. Zur politischen Topographie der Geschlechter vom 18. bis frühen 20. Jahrhundert, w: taż, „Mann und Weib, und Weib und Mann". Geschlechter-Differenzen in der Moderne, München 1995.

Funck M., Malinowski S., „Charakter ist alles!” Erziehungsideale und Erziehungspraktiken in deutschen Adelsfamilien des 19. und 20. Jahrhunderts, „Jahrbuch für Historische Bildungsforschung” 6, 2000.

Jedlicki J., Proces przeciwko miastu, w: tenże, Świat zwyrodniały Lęki i wyroki krytyków nowoczesności, Warszawa 2000.

Kizwalter T., Procesy modernizacji a emancypacja kobiet na ziemiach polskich $w$ XIX wieku, w: Kobieta $i$ społeczeństwo na ziemiach polskich $w$ XIX wieku, red. A. Żarnowska, A. Szwarc, Warszawa 1995.

Kubrova M., Vom guten Leben. Adelige Frauen im 19. Jahrhundert, Berlin 2011.

Malatesta M., The Landed Aristocracy during the Nineteenth and Early Twentieth Centuries, w: The European Way: European Societies in the $19^{\text {th }}$ and $20^{\text {th }}$ Centuries, red. H. Kaelble, New York-Oxford 2004.

Malinowski S., „Führertum” und „Neuer Adel”. Die Deutsche Adelsgenossenschaft und der Deutsche Herrenklub in der Weimarer Republik, w: Adel und Bürgertum in Deutschland, red. H. Reif, t. 2: Entwicklungslinien und Wendepunkte im 20. Jahrhundert, Berlin 2001.

Malinowski S., Vom König zum Führer. Sozialer Niedergang und politische Radikalisierung in deutscher Adel zwischen Kaiserreich und NS-Staat, Berlin 2003.

Nipperdey T., Problemy modernizacji w Niemczech, w: tenże, Rozważania o niemieckiej historii, Warszawa 1999.

Ostelbische Agrargesellschaft im Kaiserreich und in der Weimarer Republik. Agrarkrise-junkerliche Interessenpolitik-Modernisierungsstrategien, red. H. Reif, Berlin 1994. 
Osterhammel J., Historia XIX wieku. Przeobrażenie świata, Poznań 2013.

Planert U., Antifeminismus im Kaiserreich: Diskurs, soziale Formation und politische Mentalität, Göttingen 1998.

Puhle H.J, Agrarische Interessenpolitik und preußischen Konservatismus im wilhelminischen Reich (1893-1914), Bonn 1980.

Rüschmeyer D., Partielle Modernisierung, w: Theorien des sozialen Wandels, red. W. Zapf, Köln 1969.

Seelig M., Der Kampf gegen die Moderne. Krisenwahrnehmung und -bewältigung im „Deutschen Adelsblatt” um 1900, w: Krisenwahrnehmungen in Deutschland um 1900. Zeitschriften als Foren der Umbruchszeit im wilhelminischen Reich, red. M. Grunewald, U. Puschner, Bern 2010.

Singer J.M., Arme adlige Frauen im Deutschen Kaiserreich, Tübingen 2016.

Smoczyński R., Zarycki T., Wspótczesne polskie elity postszlacheckie $w$ kontekście europejskim, „Kultura i Społeczeństwo” 2012, 1.

Stępiński W., Procesy integracyjne w obrębie rodów szlacheckich na Pomorzu Zachodnim, w: Rodzina pomorska, red. J. Borzyszkowski, Gdańsk 1999.

Stępiński W., Wielka własność ziemska na Pomorzu Zachodnim i państwo pruskie w latach 1806-1914, w: Szlachta - społeczeństwo - państwo między Warmia a Rugia w XVIII-XX wieku, red. M. Jaroszewicz i W. Stępiński, Szczecin 1998.

Süchting-Hänger A., „Gleichgroße mut'ge Helferinnen” in der weiblichen Gegenwelt: Der Vaterländische Frauenverein und die Politisierung konservativer Frauen 1890-1914, w: Nation, Politik und Geschlecht: Frauenbewegungen und Nationalismus in der Moderne, red. U. Planert, Frankfurt a. M. 2000.

Süchting-Hänger A., Das „Gewissen der Nation”. Nationales Engagement und politisches Handeln konservativer Frauenorganisationen 1900-1937, Düsseldorf 2002.

Wehler H.-W., Teoria modernizacji a historia, w: tenże, Modernizacja, nacjonalizm, państwo. Eseje i artykuty, Warszawa 2001.

Wienfort M., Der Adel in der Moderne, Göttingen 2006.

Wörner-Heil O., Adelige Frauen als Pionierinnen der Berufsbildung. Die ländliche Hauswirtschaft und der Reifensteiner Verband, Kassel 2010.

Agnieszka Szudarek

How to face modernity?

Debate surrounding the model of a German noblewoman on the pages of Deutsches Adelsblatt at the turn of the $20^{\text {th }}$ century (Summary)

One of the less explored sources of information in the study of the Prussian-German nobility at the turn of the $20^{\text {th }}$ century is the weekly Deutsches Adelsblatt. It was run by an organisation established in 1874 under the name 
Deutsche Adelsgenossenschaft, whose goal was to make the nobility, which at the time was losing its influence, an important voice in the public life. The opinion pieces published on the pages of the above mentioned periodical reflect the noble mindset and allow to interpret the changes taking place in Germany undergoing rapid modernisation. In the eyes of the nobility, the industrialisation and its social and economic aftermath were a threat to the agrarian world which the nobles were a part of. The debate on the future of the nobility also encompassed the issue of the situation of women belonging to the social class in question. The aim of the paper is to present the opinions expressed in the aforementioned weekly on the subject of the influence of social-economic changes and advancement of civilisation on the life of noblewomen. Journalists used these reflections as a starting point of the re-formulation of the catalogue of female tasks and obligations, which still underlined their roles as wives, mothers, and masters on their estates, but at the same time contained new elements, such as more thorough education or even possibility of employment. The model of a modern noblewoman constructed by these means was reinforced by the class-nationalist context, which, according to the opinion of journalists, made women responsible for the future of the nobility and the country.

Agnieszka Szudarek - dr hab. nauk humanistycznych, profesor nadzwyczajny w Instytucie Historii i Stosunków Międzynarodowych Uniwersytetu Szczecińskiego. Zajmuje się historią społeczną XIX wieku. Prowadzi badania nad szlachciankami pruskimi, ruchem kobiecym w Niemczech, filantropia i historia rodziny. Jest członkiem Zespołu Badawczego Historii Kobiet Komitetu Nauk Historycznych PAN oraz Komisji Historii Kobiet przy Zarządzie Głównym PTH. E-mail: agnieszka_szudarek@wp.pl. 